\title{
Pengaruh Suplementasi Minyak Ikan Lemuru Terproteksi dan L-Carnitin Dalam Ransum Terhadap Kecernaan Bahan Kering dan Bahan Organik Pada Pakan Sapi Perah Laktasi
}

\author{
Sudibya*, K. R Akbar, W. Pratitis, dan J. Riyanto \\ Program Studi Peternakan, Fakultas Pertanian, Universitas Sebelas Maret
}

\begin{abstract}
ABSTRAK
Penelitian ini bertujuan untuk menguji pengaruh suplementasi minyak ikan lemuru terproteksi dan L-carnitine dalam ransum terhadap kecernaan bahan kering dan bahan organic pada pakan sapi perah laktasi.. Penelitian menggunakan 12 ekor sapi perah betna berumur 3-4 tahun dengan bobot badan rata-rata $400 \pm 5 \mathrm{~kg}$. Penelitian menggunakan bahan pakan yang terdiri atas rumput gajah dan ransum basal (jagung kuning, bekatul, bungkil kedele, bungkil kelapa, mineral)/ L-karnitin, minyak ikan lemuru.Penelitian menggunakan rancangan acak kelompok. Perlakuan terdiri atas:45\% jerami padi $+55 \%$ konsentrat; $\mathrm{P} 1=15 \%$ jerami padi $+30 \%$ jerami padi fermentasi $+55 \%$ konsentrat; $\mathrm{P} 2=15 \%$ jerami padi $+30 \%$ jerami padi fermentasi $+55 \%$ konsentrat +1000 ppm L-carnitin; dan P $3=15 \%$ jerami padi $+30 \%$ jerami padi fermentasi $+55 \%$ konsentrat $+1000 \mathrm{ppm}$ L-carnitin $+4 \%$ minyak ikan lemuru terproteksi. Hasil analisis variansi menunjukkan bahwa suplementasi minyak ikan lemuru terproteksi dan L-carnitin dalam ransum yang menggunakan jerami padi fermentasi berpengaruh sangat nyata $(\mathrm{P}<0,01)$ terhadap nilai konsumsi bahan kering dan konsumsi bahan organik serta nilai kecernaan bahan kering dan kecernaan bahan organik..Kesimpulan yang di dapat yaitu suplementasi minyak ikan lemuru terproteksi dan L-Carnitin mampu menurunkan konsumsi bahan kering dan bahan organik serta meningkatkan nilai kecernaan bahan kering dan kecernaan bahan organik.
\end{abstract}

Kata kunci: Daya cerna, L-carnitine, Minyak ikan lemuru, Sapi perah laktasi

\section{Effect of Protected Lemuru Fish Oil and L-Carnitine Supplementation on Dry Matter and Organic Matter Digestibility of Dairy Cattle}

\begin{abstract}
This study aimed to determine the effect of supplementation lemuru fish oil protected and L-carnitine on digestibility value of lactating dairy cows. The materials used were 12 lactating dairy cows with average body weight $400 \pm 5 \mathrm{~kg}$. The study design was a randomized block design with 4 treatments and each treatment consisting of 3 blocks, each block contains one period of lactation dairy cows. Treatments were $P 0=45 \%$ rice straw $+55 \%$ concentrate; $P 1=15 \%$ rice straw $+30 \%$ fermented rice straw $+55 \%$ concentrate; $P 2=15 \%$ rice straw $+30 \%$ fermented rice straw $+55 \%$ concentrate +1000 ppm $L$-carnitine; and $P 3=15 \%$ rice straw $+30 \%$ rice straw fermented rice straw $+55 \%$ concentrate +1000 ppm L-carnitine + $4 \%$ protected lemuru fish oil. . The results of variance analysis showed that supplementation protected lemuru fish oil and Lcarnitine in the diet rice straw fermentation was high significantly increased $(P<0.01)$ on dry matter intake, consumption as well as dry matter digestibility and digestibility of organic matter in lactating dairy cows. It could be concluded that supplementation protected lemuru fish oil and L-carnitine in the diet of rice straw fermented able to reduce the consumption of dry matter and organic matter and increase the value of dry matter and organic matter digestibility.
\end{abstract}

Keywords: Digestibility, Lactating dairy cows, Lemuru fish oil, L-carnitine

\section{PENDAHULUAN}

Ternak ruminansia mengunakan karbohidrat sebagai sumber energi utamanya, sedangkan energi cadangan berasal dari lemak. Minyak dimanfaatkan sebagai sumber energi pendukung di dalam pakan karena mahalnya bahan pakan sumber energi, penambahan minyak seperti minyak ikan lemuru kedalam pakan merupakan cara yang paling cocok untuk memenuhi kebutuhan energi yang tinggi. Minyak ikan lemuru mengandung asam lemak tak jenuh dan tinggi akan asam lemak omega-3 sebagai sumber energi (Sudibya et al., 2004). Diperlukan suatu metode agar minyak ikan tidak terhidrogenasi di rumen yaitu dengan proteksi diharapkan lemak tidak terhidrogenasi, selain itu diharapkan proteksi

\footnotetext{
*Penulis Korespondensi: Sudibya

Alamat: Jl. Ir. Sutami 36A Kentingan, Surakarta, jawa Tengah

E-mail: sudibya@staff.uns.ac.id.
}

dapat meningkatkan kecernaan (Sudibya et al., 2009). Selanjutnya penggunaan minyak ikan optimum dalam ransum kambing, pedaging, domba, sapi potong dan kambing perah masing-masing sebesar 4\% dalam ransum (Sudibya et al., 2007; Sudibya et al., 2010; Sudibya et al., 2009; Sudibya et al., 2015 dan Sudibya et al., 2016).

L-Carnitin adalah senyawa yang mengandung nitrogen dengan berat molekul rendah yang membantu oksidasi asam lemak rantai panjang ke dalam mitokondria dan merangsang tindakan penghematan protein dengan meningkatkan energi (Hajibabaei et al., 2008). Penggunaan 1-karnitin dalam ransum konsentrasinya 2-3 kali bobot badanya.

Suplementasi asam lemak tak jenuh terproteksi dan L-carnitin pada ternak ruminansia dapat memberi keseimbangan energi pada sapi perah yaitu untuk hidup pokok dan produksi susu serta mencegah terjadinya penurunan bobot badan pada masa laktasi, 
pemberian asam lemak tak jenuh sekitar 4\% serta berkurangnya asam lemak jenuh dapat meningkatkan kecernaan pada sapi perah.

Penelitian ini bertujuan untuk mengetahui pengaruh suplementasi minyak ikan lemuru terproteksi dan L-carnitin dalam ransum basal jerami padi fermentasi terhadap nilai konsumsi bahan kering, konsumsi bahan organik, kecernaan bahan kering dan kecernaan bahan organik sapi perah laktasi.

\section{MATERI DAN METODE}

\section{Materi}

Minyak ikan lemuru yang dibeli dari Kecamatan Muncar Jawa Timur yang diperoleh secara ekstrasi dan L-karnitin dibeli pada Apotek berupa kapsul dan setiap kapsul berisi 500 ppm dengan warna putih. Selanjutnya ternak yang digunakan dalam penelitian ini adalah sapi perah peranakan Frisien Holstein (PFH) laktasi sebanyak 12 ekor dengan bobot badan $300-450 \mathrm{~kg}$ dan produksi susu $14-16$ liter dengan kadar lemak 4 persen yang ditempatkan pada kandang individu.

Produk minyak ikan lemuru terproteksi dibuat melalui proses penyabunan. Penyabunan dengan cara minyak ikan lemuru dipanaskan dengan suhu 60 $80^{\circ} \mathrm{C}$ selama 10 menit, kemudian dicampur larutan $\mathrm{NaOH} 10 \%$ sambil diaduk dan ditambahkan larutan pati $10 \%$ sampai membentuk pasta yang liat, dengan perbandingan minyak ikan, $\mathrm{NaOH}$, tepung $1: 2: 1$.
Gumpalan didiamkan selama satu malam agar mengeras. Gumpalan sabun yang diperoleh dikristalkan melalui perendaman dengan larutan $\mathrm{CaCl}_{2}$ jenuh selama 2 jam selanjutnya dikeringkan dan di jemur.

Penelitian ini menggunakan rancangan acak kelompok (RAK) dengan 4 macam perlakuan. Setiap perlakuan terdiri dari 3 blok, yang mana blok 1 (bobot sapi $300-350 \mathrm{~kg}$ ), blok 2 (bobot 350-400 kg) dan blok 3 (bobot 400-450 kg) dan setiap blok berisi 1 ekor sapi perah laktasi (Tabel 1).

Tabel 1. Bobot badan awal sapi perah laktasi yang digunakan $(\mathrm{kg})$

\begin{tabular}{lcccc}
\hline B1ok & P0 & P1 & P2 & P3 \\
\hline B1 & 327 & 337 & 381 & 388 \\
B2 & 352 & 363 & 402 & 417 \\
B3 & 377 & 350 & 422 & 446 \\
\hline
\end{tabular}

Adapun perlakuan yang diberikan sebagai berikut:

- $\quad \mathrm{P} 0=45 \%$ Jerami padi $+55 \%$ konsentrat

- $\quad \mathrm{P} 1=15 \%$ Jerami padi $+30 \%$ jerami padi fermentasi $+55 \%$ konsentrat

- $\quad \mathrm{P} 2=\mathrm{P} 1+0,1 \%$ L-carnitin setara $1000 \mathrm{ppm}$

- $\quad \mathrm{P} 3=\mathrm{P} 2+4 \%$ minyak ikan lemuru terproteksi

\section{Metode}

Tahap persiapan kandang meliputi pembersihan kandang dan tempat pakan. Menyediakan peralatan yang dibutuhkan, di cuci dan kemudian di keringkan

Tabel 2. Susunan ransum dan kandungan nutriennya (\% dasar BK)

\begin{tabular}{|c|c|c|c|c|}
\hline \multirow[t]{2}{*}{ Bahan Pakan } & \multicolumn{4}{|c|}{ "Komposisi Pakan (\%) } \\
\hline & $\mathrm{P} 0$ & $\mathrm{P} 1$ & $\mathrm{P} 2$ & $\mathrm{P} 3$ \\
\hline \multicolumn{5}{|l|}{ Hijauan } \\
\hline Jerami Padi & 45 & 15 & 15 & 15 \\
\hline Jerami Padi Fermentasi & - & 30 & 30 & 30 \\
\hline \multicolumn{5}{|l|}{ Konsentrat } \\
\hline Bekatul & 20 & 20 & 20 & 20 \\
\hline Onggok & 10 & 10 & 10 & 10 \\
\hline Bungkil kedelai & 8 & 8 & 8 & 8 \\
\hline Bran & 6 & 6 & 6 & 6 \\
\hline Bungkil sawit & 4 & 4 & 4 & 4 \\
\hline Kopra & 2 & 2 & 2 & 2 \\
\hline Ampas tahu & 5 & 5 & 5 & 5 \\
\hline \multicolumn{5}{|l|}{ Bahan Perlakuan } \\
\hline Minyak Ikan Lemuru Terproteksi & - & - & - & 4 \\
\hline L-carnitin & - & - & 0,1 & 0,1 \\
\hline Jumlah & 100 & 100 & 100,1 & 104,1 \\
\hline \multicolumn{5}{|l|}{ Kandungan Nutrien (\%) } \\
\hline Bahan Kering (BK) & 82,94 & 86,77 & 86,86 & 93,81 \\
\hline Protein Kasar (PK) & 9,71 & 10,63 & 10,65 & 12,29 \\
\hline Lemak Kasar (LK) & 4,35 & 4,87 & 4,88 & 5,38 \\
\hline Serat Kasar (SK) & 20,23 & 19,50 & 19,50 & 20,38 \\
\hline Bahan Organik (BO) & 81,43 & 81,82 & 81,90 & 85,15 \\
\hline TDN & 62,55 & 65,62 & 65,62 & 68,40 \\
\hline \multicolumn{5}{|l|}{ Kandungan Nutrien (\% BK) } \\
\hline Bahan Kering $(\mathrm{BK})$ & 82,94 & 86,77 & 86.77 & 90.11 \\
\hline Protein Kasar (PK) & 9,71 & 10,63 & 10.63 & 11,80 \\
\hline Lemak Kasar (LK) & 4,35 & 4,87 & 4,87 & 5,16 \\
\hline Serat Kasar (SK) & 20,23 & 19,50 & 19.48 & 19,43 \\
\hline Bahan Organik (BO) & 81,43 & 81,82 & 81,81 & 81,79 \\
\hline TDN & 62,55 & 65,62 & 65,55 & 65,70 \\
\hline
\end{tabular}


di bawah sinar matahari. Persiapan sapi .Sapi yang digunakan adalah sapi yang sedang dalam masa laktasi. Selanjutnya sapi-sapi percobaan dilakukan adaptasi pakan selama 14 hari.

Ransum yang digunakan dalam penelitian terdiri dari jerami padi, jerami padi fermentasi, konsentrat basal, minyak ikan lemuru terproteksi dan L-carnitin. Konsentrat basal terdiri dari onggok, bungkil sawit, bekatul, bungkil kedelai, bran dan kopra. Bahan untuk pembuatan jerami padi fermentasi (JPF) adalah 1 ton jerami padi, $1 \mathrm{~kg}$ starbio, dan 2 liter molasses (Tabel 2).

Penelitian ini dilaksanakan melalui tiga tahap, yaitu adaptasi pakan perlakuan, koleksi data dan menganalisis data.

\section{Peubah Penelitian}

Peubah penelitian yang diamati adalah (1) Konsumsi Bahan Kering (BK) (kg/ekor/hari) yaitu Konsumsi $\mathrm{BK}=($ pemberian $\mathrm{x} \% \mathrm{BK})-($ sisa $\mathrm{x} \% \mathrm{BK}$ pakan), (2) Konsumsi Bahan Organik yaitu Konsumsi $\mathrm{BO}=$ Konsumsi $\mathrm{BK} \times$ \% BO, (3) Kecernaan Bahan Kering (\%) yaitu Kecernaan BK= konsumsi BK - BK feses x 100\% dibagi konsumsi BK, dan (4) Kecernaan Bahan Organik (BO) yaitu Kecernaan BO = Konsumsi $\mathrm{BO}-\mathrm{BO}$ feses $\mathrm{x} 100 \%$ dibagi konsumsi BO

\section{Analisis Data}

Semua data yang diperoleh dalam penelitian dianalisis dengan menggunakan analisis ragam atau Analysis of Variance (ANOVA) untuk mengetahui adanya pengaruh perlakuan terhadap peubah yang diamati. Karena terdapat perbedaan dilanjutkan uji kontras orthogonal (Astuti, 1980).

\section{HASIL DAN PEMBAHASAN}

Rerata yang diperoleh dari hasil penelitian suplementasi minyak ikan lemuru terproteksi dan Lcarnitin dalam ransum jerami padi fermentasi Konsumsi Bahan Kering (kg/ekor/hari), Konsumsi Bahan Organik (kg/ekor/hari), Kecernaan Bahan Kering (\%), Kecernaan Bahan Organik (\%) sapi perah laktasi. Bahan kering adalah bahan yang terkandung di dalam pakan setelah dihilangkan kandungan airnya (Tillman et al., 1991). Rerata konsumsi bahan kering sapi perah laktasi yang diperoleh selama penelitian dapat dilihat pada Tabel 3 dan Tabel 4. Rerata konsumsi bk pada penelitian ini secara berturut turut dari P0, P1, P2 dan P3 yaitu 9,25; 8,87; 8,54 dan 7,50 $\mathrm{kg} / \mathrm{ekor} / \mathrm{hari}$. Hasil analisis variansi pengaruh suplementasi minyak ikan lemuru terproteksi dan L- carnitin dalam ransum menunjukkan hasil berbeda sangat nyata $(\mathrm{P}<0,01)$ terhadap konsumsi bahan kering. Bedasarkan Uji Lanjut Kontras Orthogonal konsumsi $\mathrm{BK}$ pada $\mathrm{P} 0$ berpengaruh sangat nyata $(\mathrm{P}<0,01)$ terhadap $\mathrm{P} 1, \mathrm{P} 2$, dan $\mathrm{P} 3$. Hal ini disebabkan karena pada P1 hingga P3 perlakuan menggunakan campuran jerami padi biasa dengan jerami padi fermentasi, jerami padi fermentasi memiliki kandungan nutrien yang lebih baik dibanding dengan jerami padi biasa serta memiliki aroma harum yang lebih disukai oleh sapi maka dapat meningkatkan nutrien pakan, terlihat pada kandungan TDN ransum, pada P0 memiliki kandungan TDN sebesar 62,55\% sedangkan pada P1 sampai P3 kandungan TDN sebesar $62,62 \% ; \quad 65,55 \%$ dan $65,70 \%$ yang menyebabkan terjadinya penurunan konsumsi BK.

Konsumsi BK pada P1 berpengaruh nyata terhadap P2 dan P3. Pada P2 ransum menggunakan suplementasi L-carnitin $0,1 \%$ atau setara dengan $100 \mathrm{ppm}$, suplementasi L-carnitin dalam ransum pakan menunjukkan tingkat konsumsi yang berbeda sangat nyata. Hal ini disebabkan karena fungsi utama Lcarnitin yang mempengaruhi konsumsi pakan dengan membantu metabolisme yang diperlukan untuk mengoksidasi asam lemak rantai panjang dalam mitokondria (Flanagan et al., 2010). Untuk P3 yang ditambahkan minyak ikan lemuru terproteksi bau amis sudah terkurangi oleh proses proteksi, minyak ikan lemuru terproteksi berbentuk pasta yang dikeringkan.

Adanya penurunan konsumsi bahan kering pada P1 sampai P3 kemungkinan karena adanya peningkatan kualitas pakan salah satunya energi dari lemak. Hal ini disebabkan karena minyak ikan lemuru mengandung energi yang cukup tinggi, sehingga kebutuhan energi sapi perah lebih cepat terpenuhi. Hal tersebut sejalan dengan pendapat Joseph (2007) yang menyatakan bahwa suplementasi sabun kalsium ternyata dapat meningkatkan kualitas ransum sehingga konsumsinya yang sedikit tetapi memiliki nutrien yang jauh lebih baik menjadikan ternak kenyang secara kimia.

Pada P2 berpengaruh sangat nyata terhadap P3, dikarenakan pada P3 suplementasi minyak ikan lemuru terproteksi diberikan pada level 4\% serta Lcarnitin $0,1 \%$ jadi ransum P3 mampu memberikan sumber energi pada sapi perah kemudian metabolismenya dibantu oleh peran dari L-carnitin yang mengoksidasi asam lemak rantai panjang dalam mitokondria. Davies (1982) menjelaskan bahwa kandungan energi pakan berbanding terbalik dengan tingkat konsumsinya, makin tinggi kandungan energi di dalam pakan, maka jumlah konsumsinya akan

Tabel 3. Rerata konsumsi BK, konsumsi BO, kecernaan BK, kecernaan BO (blok)

\begin{tabular}{lccc}
\hline \multicolumn{1}{c}{ Peubah } & & Blok & $\mathrm{B} 3$ \\
\cline { 2 - 4 } Konsumsi BK (kg/ekor/hari) & $\mathrm{B} 1$ & $\mathrm{~B} 2$ & $8.69^{\mathrm{B}}$ \\
Konsumsi BO (kg/ekor/hari) & $8.34^{\mathrm{A}}$ & $8.61^{\mathrm{B}}$ & $6.53^{\mathrm{B}}$ \\
Kecernaan BK (\%) & $6.26^{\mathrm{A}}$ & $6.47^{\mathrm{B}}$ & 52.06 \\
Kecernaan BO (\%) & 51.01 & 51.23 & 46.41 \\
\hline Keterangan: Huruf dengan superskrip yang berbeda pada baris yang sama menunjukkan ada perbedaan sangat nyata (P<0,01).
\end{tabular}


Tabel 4. Rerata konsumsi BK, konsumsi BO, kecernaan BK, kecernaan BO

\begin{tabular}{lcccc}
\hline \multirow{2}{*}{ Peubah } & \multicolumn{3}{c}{ Perlakuan } \\
\cline { 2 - 5 } & P0 & P1 & P2 & P3 \\
\hline Konsumsi BK (kg/ekor/hari) & $9.25^{\mathrm{D}}$ & $8.87^{\mathrm{C}}$ & $8.54^{\mathrm{B}}$ & $7.50^{\mathrm{A}}$ \\
Konsumsi BO (kg/ekor/hari) & $6.94^{\mathrm{D}}$ & $6.68^{\mathrm{C}}$ & $6.46^{\mathrm{B}}$ & $5.59^{\mathrm{A}}$ \\
Kecernaan BK (\%) & $44.17^{\mathrm{A}}$ & $49.29^{\mathrm{B}}$ & $54.74^{\mathrm{c}}$ & $57.53^{\mathrm{d}}$ \\
Kecernaan BO (\%) & $37.38^{\mathrm{A}}$ & $43.14^{\mathrm{B}}$ & $49.81^{\mathrm{c}}$ & $52.90^{\mathrm{d}}$ \\
\hline
\end{tabular}

Keterangan: Huruf besar dengan superskrip yang berbeda pada baris yang sama menunjukkan ada perbedaan sangat nyata (P<0,01). Huruf kecil dengan superskrip yang berbeda pada baris yang sama menunjukkan ada perbedaan nyata $(\mathrm{P}<0,05)$.

menurun. Sebaliknya, konsumsi pakan akan meningkat jika kandungan energi yang terdapat pada pakan rendah.

Konsumsi BK juga dipengarui oleh blok, hasil analisis variansi pada blok menunjukan perbedaan sangat nyata $(\mathrm{P}<0,01)$. Bedasarkan Uji lanjut kontras orthogonal Konsumsi BK pada B1 berpengaruh sangat nyata $(\mathrm{P}<0,01)$ terhadap $\mathrm{B} 2$ dan B3 (Tabel 5). Ditambahkan Sarwono dan Arianto (2007), kemampuan sapi mengkonsumsi ransum sangat terbatas. Keterbatasan itu dipengaruhi oleh faktor ternak meliputi bobot badan sapi. Perkiraan kemampuan sapi mengkonsumsi BK ransum berdasarkan berat badan $300-350$ yaitu $2,8 \%$ dari bobot badan, berat badan $350-400$ yaitu $2,6 \%$ dari bobot badan, untuk berat badan 400 - 450 yaitu $2,4 \%$ dari bobot badan. Jadi semakin tinggi bobot badan maka kemampuan mengkonsumsi $\mathrm{BK}$ ransum semakin rendah. Untuk B2 Berpengaruh tidak nyata $(\mathrm{P}>0,05)$ terhadap $\mathrm{B} 3$. Hal ini dikarenakan rentang bobot badan antara B2 dengan B3 tidak terlalu jauh jadi konsumsi BK berpengaruh tidak nyata.

Tabel 5. Hasil uji kontras ortogonal konsumsi BK

\begin{tabular}{lc}
\hline Kontras Antar Perlakuan & Signifikansi \\
\hline P0 vs P1, P2, P3 & $* *$ \\
P1 vs P2, P3 & $* *$ \\
P2 vs P3 & $* *$ \\
B1 vs B2, B3 & $* *$ \\
B2 vs B3 & NS
\end{tabular}

Keterangan: $* *(\mathrm{P}<0,01)$ menunjukkan pengaruh sangat nyata. ${ }^{\mathrm{NS}}(\mathrm{P}>0,05)$ menunjukkan pengaruh tidak nyata.

\section{Konsumsi Bahan Organik (BO)}

Bahan organik merupakan bahan kering yang telah dikurangi kandungan abu, komponen bahan kering bila difermentasi di dalam rumen akan menghasilkan asam lemak terbang yang merupakan sumber energi bagi ternak (Arora, 1989). Rerata konsumsi bahan organik sapi perah laktasi yang diperoleh selama penelitian dapat dilihat pada Tabel 3 dan Tabel 4. Rerata konsumsi BO pada penelitian ini secara berturut turut dari P0, P1, P2 dan P3 yaitu 6,94; 6,$68 ; 6,46$ dan 5,59 kg/ekor/hari. Hasil analisis variansi pengaruh suplementasi minyak ikan lemuru terproteksi dan L-carnitin dalam ransum menunjukkan hasil berbeda sangat nyata $(\mathrm{P}<0,01)$ terhadap konsumsi BO.

Bedasarkan Uji Lanjut Kontras Orthogonal konsumsi BO P0 berpengaruh sangat nyata $(\mathrm{P}<0,01)$ terhadap P1, P2, dan P3 (Tabel 6). Bahan organik merupakan bagian dari bahan kering. Pada P0 diberi jerami padi dan konsentrat, jerami padi mempunyai kandungan TDN sebesar $45,40 \%$ dan pada ransum yang diberi jerami padi fermentasi dan konsentrat, kandungan TDN jerami padi fermentasi sebesar $55,42 \%$, Kemudian untuk kandungan TDN total ransum, pada P0 memiliki kandungan TDN sebesar $62,55 \%$ sedangkan pada P1 sampai P3 kandungan TDN sebesar 62,62\%; 65,55\% dan 65,70\%. Hasil yang berbeda sangat nyata di duga karena kandungan TDN jerami padi fermentasi lebih tinggi dari TDN jerami padi karena penggunaan jerami padi fermentasi jadi kebutuhan bahan organik lebih tercukupi akibatnya konsumsi BO lebih rendah. Konsumsi BO P1 berpengaruh sangat nyata terhadap P2 dan P3.

Tabel 6. Hasil uji kontras ortogonal konsumsi BO

\begin{tabular}{lc}
\hline \hline Kontras Antar Perlakuan & Signifikansi \\
\hline P0 vs P1, P2, P3 & $* *$ \\
P1 vs P2, P3 & $* *$ \\
P2 vs P3 & $* *$ \\
B1 vs B2, B3 & $* *$ \\
B2 vs B3 & NS \\
\hline
\end{tabular}

Keterangan: $* *(\mathrm{P}<0,01)$ menunjukkan pengaruh sangat nyata ${ }^{\mathrm{NS}}(\mathrm{P}>0,05)$ menunjukkan pengaruh tidak nyata.

Pemberian L-carnitin berpengaruh sangat nyata terhadap konsumsi BO dikarenakan L-carnitin meningkatkan efisiensi sintesis energi dalam tubuh sapi perah jadi dapat membantu pakan ransum lebih cepat diubah menjadi energi akibatnya konsumsi BO lebih rendah. Parakkasi (1999) menyatakan bahwa yang membatasi tingkat konsumsi ternak adalah kebutuhan energi. Ternak akan berhenti makan apabila kebutuhan energinya telah terpenuhi. P2 berbeda sangat nyata terhadap P3.

Pemberian L-carnitin dan minyak ikan lemuru terproteksi pada level $4 \%$ berpengaruh sangat nyata terhadap konsumsi BO dikarenakan minyak ikan lemuru memberikan energi serta asam lemak tak jenuh bagi sapi perah, dengan dibantu L-carnitin metabolisme lemak akan dipermudah untuk masuk kedalam mitokondria, jadi akan mengalami penurunan konsumsi BO karena peningkatan kualitas pakan dan peningkatan energi dari ransum. Hal ini sejalan dengan pendapat Kamal (1994) yang menyatakan bahwa konsumsi bahan organik erat kaitannya dengan konsumsi bahan kering. Apabila perlakuan berpengaruh sangat nyata terhadap bahan kering maka konsumsi bahan organik juga berpengaruh sangat nyata.

Lebih lanjut dijelaskan oleh Astuti et al (2009) bahwa semakin tinggi atau rendahnya konsumsi bahan 
kering maka konsumsi bahan organik juga mengikuti konsumsi bahan kering tersebut. Konsumsi BO juga dipengarui oleh blok, hasil analisis variansi pada blok menunjukan perbedaan sangat nyata $(\mathrm{P}<0,01)$. Bedasarkan Uji lanjut kontras orthogonal Konsumsi BO pada B1 berpengaruh sangat nyata $(\mathrm{p}<0,01)$ terhadap B2 dan B3. Hal ini dikarenakan kemampuan sapi untuk mengkonsumsi BO terbatas, salah satu faktornya disebabkan oleh bobot badan sapi tersebut. Untuk B2 Berpengaruh tidak nyata $(p>0,05)$ terhadap B3. Jadi bobot badan sapi perah yang tidak terlalu jauh rentangnya tidak mempengaruhi konsumsi BO.

\section{Kecernaan Bahan Kering (KcBK)}

Rerata kecernaan bahan kering sapi perah laktasi yang diperoleh selama penelitian dapat dilihat pada Tabel 3 dan Tabel 4.

Tabel 7. Hasil uji kontras ortogonal kecernaan BK

\begin{tabular}{lc}
\hline \multicolumn{1}{c}{ Kontras Antar Perlakuan } & Signifikansi \\
\hline P0 vs P1, P2, P3 & $* *$ \\
P1 vs P2, P3 & $* *$ \\
P2 vs P3 & $*$ \\
\hline
\end{tabular}

Keterangan: $* *(\mathrm{P}<0,01)$ menunjukkan pengaruh sangat nyata $*(\mathrm{P}<0,05)$ menunjukkan pengaruh nyata.

Rerata kecernaan BK berturut-turut dari P0, P1, P2 dan P3 adalah 44,17; 49,29; 54,74 dan 57,53 persen. Dari hasil analisis variansi bahwa pengaruh suplementasi minyak ikan lemuru terproteksi dan $L$ carnitin dalam ransum menunjukkan hasil yang berbeda sangat nyata $(\mathrm{P}<0,01)$ terhadap kecernaan bahan kering. Beberapa faktor yang mempengaruhi kecernaan BK yaitu bentuk fisik bahan pakan, komposisi ransum, laju perjalanan melalui alat pencernaan dan pengaruh terhadap perbandingan dari zat pakan lainnya (Anggorodi, 1984). Bedasarkan Uji lanjut kontras orthogonal kecernaan BK P0 berpengaruh sangat nyata pengaruhnya terhadap komposisi kimiawi air susu sapi perahterhadap P1, P2, dan P3 (Tabel 7).

Kecernaan BK pada perlakuan yang diberi campuran jerami padi fermentasi dan konsentrat menunjukkan hasil yang lebih baik dari pada perlakuan yang hanya diberi jerami padi dan konsentrat, hal ini diduga karena adanya penurunan kandungan SK pada jerami padi fermentasi yaitu 14,74 persen, sedangkan SK jerami padi sebesar 17,18 persen, kandungan komponen serat kasar yang lebih tinggi akan memperlambat laju alir nutrien dalam saluran pencernaan sekaligus mengakibatkan makin lamanya waktu tinggal pakan dalam saluran pencernaan. Daya cerna suatu bahan pakan juga tergantung pada keserasian nutrien yang terkandung di dalam pakan. Pada ternak ruminansia apabila tidak terdapat satu dari nutrient yang diperlukan untuk pertumbuhan mikroorganisme, maka daya cernanya akan berkurang. Akibatnya kadar karbohidrat yang tinggi yang akan mengurangi daya cerna serat kasar. Kecernaan bahan kering mengalami peningkatan pada pakan yang diberi jerami padi yang telah difermentasi.
Fermentasi di luar tubuh ternak mempunyai peran meningkatkan nilai nutrisi bahan pakan dan kecernaannya. Hasil fermentasi akan mempunyai nilai gizi yang tinggi yaitu mengubah bahan makanan yang mengandung protein, lemak dan karbohidrat yang sulit dicerna menjadi mudah dicerna. Bahan pakan terfermentasi memiliki kecernaan lebih tinggi dibandingkan dengan yang tidak difermentasi. Hal ini memperkuat pernyataan Lubis, et al. (2002), bahwa penggunaan produk fermentasi akan meningkatkan kecernaan bahan kering ransum. Produk pakan yang telah difermentasi sangat kondusif untuk mikroba rumen berkembang biak dan bekerja lebih efektif. Pada P1 juga berbeda sangat nyata $(\mathrm{P}<0,01)$ terhadap $\mathrm{P} 2$ dan $\mathrm{P} 3$. Hal tersebut dikarenakan penggunaan $L$-carnitin yang memiliki fungsi membantu sintesis asam lemak menjadi energi. L-carnitin mempercepat aliran pencernaan untuk dicerna maka semakin cepat daya cerna pakan maka kecernaan BK juga akan meningkat. Untuk P2 berbeda nyata terhadap P3 $(\mathrm{P}<0,05)$. Hal ini menunjukkan bahwa penggunaan minyak ikan lemuru yang telah diproteksi tidak mengganggu sistem fermentasi di dalam rumen, lemak jenuh dalam ransum akan dihidrolisis menjadi energi kemudian digunakan untuk hidup pokok dan produksi susu sedangkan lemak tak jenuh akan terbawa masuk karena melalui proses proteksi yang mengakibatkan tidak terjadi proses hidrolisis hingga nantinya asam lemak tak jenuh tersebut akan terkandung didalam susu, metabolisme energi akan lebih cepat dengan penggunaan L-carnitin, akibatnya kecernaan BK meningkat. Kecernaan yang mempunyai nilai tinggi mencerminkan besarnya sumbangan nutrien tertentu pada ternak, sementara itu pakan yang mempunyai kecernaan rendah menunjukkan bahwa pakan tersebut kurang mampu menyuplai nutrien untuk hidup pokok maupun untuk tujuan produksi ternak (Yusmadi, 2008). Kecernaan bahan kering juga berkaitan dengan konsumsi bahan kering pakan. Menurut Tillman et al. (1991), bahwa ada keterkaitan antara daya cerna dan kecepatan pencernaan, serta antara daya cerna ransum dan konsumsi pakan.

\section{Kecernaan Bahan Organik (KcBO)}

Rerata kecernaan bahan organik sapi perah laktasi yang diperoleh selama penelitian dapat dilihat pada Tabel 3 dan Tabel 4. Rerata kecernaan BO berturut-turut dari P0, P1, P2 dan P3 adalah 37,38; 43,$18 ; 49,81$ dan 52,90 persen. Dari hasil analisis variansi pengaruh suplementasi minyak ikan lemuru terproteksi dan $L$-carnitin dalam ransum menunjukkan hasil yang berbeda sangat nyata $(\mathrm{P}<0,01)$ terhadap kecernaan bahan organik.

Hasil uji kontras orthogonal menunjukkan bahwa P0 berbeda sangat nyata dengan P1, P2 dan P3. P0 menggunakan jerami padi dan konsentrat sedangkan pada ransum yang lain menggunakan campuran jerami padi dan jerami padi fermentasi serta 
konsentrat (Tabel 8). Penggunaan jerami padi fermentasi dari hasil kondisi fisik lebih remah, aromanya lebih harum dan kemungkinan rasanya juga lebih enak sedangkan pada jerami padi tidak terjadi perubahan fisik maupun perubahan rasa. Menurut Lubis, et al. (2002), semakin tinggi fermentabilitas suatu bahan pakan, maka kemungkinan untuk dicerna oleh mikroba rumen juga meningkat. Kecernaan bahan organik menunjukkan jumlah nutrien seperti lemak, karbohidrat dan protein yang dapat dicerna oleh ternak (Elita, 2006).

Tabel 8. Hasil uji kontras ortogonal kecernaan BO

\begin{tabular}{lc}
\hline \multicolumn{1}{c}{ Kontras Antar Perlakuan } & Signifikansi \\
\hline P0 vs P1, P2, P3 & $* *$ \\
P1 vs P2, P3 & $* *$ \\
P2 vs P3 & $*$
\end{tabular}

Keterangan: $* *(\mathrm{P}<0,01)$ menunjukkan pengaruh sangat nyata. $*(\mathrm{P}<0,05)$ menunjukan pengaruh nyata.

Peningkatan kecernaan bahan organik dikarenakan kecernaan bahan kering juga meningkat. Adanya peningkatan kandungan protein kasar akan menyebabkan meningkatnya aktivitas mikrobia rumen, digesti terhadap bahan organik. Ketersediaan bahan organik sederhana yang dapat dimanfaatkan oleh mikroba rumen semakin meningkat yang mengakibatkan mikroba rumen dapat berkembang biak dengan baik dan bekerja lebih optimal sehingga bahan organik tercerna dengan mudah. Pada P1 berbeda sangat nyata dengan P2 dan P3. Hal ini dikarenakan P2 disuplementasi oleh L-carnitin, $L$ carnitin mempunyai fungsi utama menyediakan suatu shuttle molecule yang berperan sebagai transfer asam lemak rantai panjang (ester asil carnitin) dari sitosol ke dalam mitokondria. Maka ransum pakan akan lebih cepat tercerna dengan penggunaan L-carnitin akibatnya kecernaan BO meningkat. Untuk P2 berbeda nyata $(\mathrm{P}<0,05)$ dengan $\mathrm{P} 3$, pemberian minyak ikan lemuru terproteksi pada level $4 \%$ dan L-carnitin $0,1 \%$ tidak menggangu aktifitas mikroba dalam rumen. Dengan aktifitas mikrobia rumen yang tidak terganggu, maka aktifitas mikrobia akan optimal dalam mendegadrasi secara fermentatif bahan organik pakan menjadi senyawa sederhana yang mudah larut, akibatnya dapat meningkatkan penyerapan zat-zat organik. Menurut Harjanto, (2005) bahwa semakin banyak mikrobia yang terdapat dalam rumen maka jumlah pakan tercerna akan semakin tinggi pula. Peningkatan kecernaan bahan organik dikarenakan kecernaan bahan kering juga meningkat. Adanya peningkatan kandungan protein kasar akan menyebabkan meningkatnya aktivitas mikrobia rumen, digesti terhadap bahan organik.

\section{KESIMPULAN}

Suplementasi minyak ikan lemuru terproteksi hingga level 4\% dan L-carnitin 1000 ppm dalam ransum jerami padi fermentasi mampu mengurangi konsumsi bahan kering dan bahan organik dan dapat meningkatkan nilai kecernaan bahan kering dan kecernaan bahan organik.

\section{DAFTAR PUSTAKA}

Adnan, M. 1980. Lipid Properties and Stability of Partially Defatted Peanuts. Disertation Doctor. University of Illinois at Urbana. Champaign.

AOAC, 1990.O fficial Methods of Analysis of the Association of Official Analytical Chemists.Association of Official Analytical Chemist, Washington, D.C.

AOAC, 2001.Official Methods of Analysis of the Association of Official Analytical Chemists. Association of Official Analytical Chemist, Washington, D.C.

Apriyantono, A., D. Fardiaz, N.L. Puspitasari, Sedarnawati dan S. Budiyanto, 1989.Petunjuk Laboratorium Analisis Pangan. Pusat Antar Universitas Pangan dan Gizi IPB Bogor.

Assman, G. 1982. Lipid metabolism and Atherosclerosis Schattaver.Verlag Stuffgart.

Astuti, M. 1980. Rancangan Percobaan dan Analisis Statistika. Fakultas Peternakan. Universitas Gadjah Mada, Yogyakarta.

Astuti, A., A. Agus dan S. P. S. Budhi. 2009. Pengaruh penggunaan high quality feed supplement terhadap konsumsi dan kecernaan nutrien sapi perah awal laktasi. Buletin Peternakan. Fakultas Peternakan. Universitas Gadjah Mada, Yogyakarta. 33(2): 81-87.

Cherian, G. and J. S. Sim. 1992. Preferential Accumulation of n-3 fatty acids in the brain of chicks from eggs enriched with n-3 fatty acids. Poultry Science 71:1658-1668.

Davies, L. H. 1982. Nutrition and growth manual. Australian Universities Development Program (AUDP), Australia.

Elita, A.S. 2006. Studi Perbandingan Penampilan Umum dan Kecernaan Pakan pada Kambing dan Domba Lokal. (Tidak Dipublikasi). Fakultas Peternakan, Institut Pertanian Bogor, Bogor.

Feller, A. G. and D. Rudman. 1988. Role of carnitine in human nutrition. Journal of Nutrition 118: 541-547.

Flanagan, J. L., P. A. Simmons, J. Vehige, M. D. P. Willcox and Q. Garret. 2010. Role of carnitine in disease. Nutrition and Metabolism 7(1): 30-44.

Harjanto, K. 2005. Pengaruh Penambanhan Probiotik Bio H+ Terhadap Kecernaan Bahan Kering dan Bahan Organik Ransum Sapi PFH Jantan. Fakultas Pertanian UNS. Surakarta

Hajibabaeia, A. A. D., M, Shivazadb., Sh, Golzar Adabic., S. Lavaf A and N. Eila. 2008" Lcarnitine Improves Egg Production in Black Neck Ostriches”. Islamic Azad University. Iran. J. Department of Animal Science. 
Hunter, J. E. 1987. PUFA and eicosanoid research. Journal of the American Oil Chemists' Society 64(8):1088-1092.

Joseph, G. 2007. Suplementasi Sabun Kalsium dalam Ransum Ternak Ruminansia Sebagai Sumber Energi Alternatif untuk Meningkatkan Produksi Daging yang Berkualitas. Disertasi Pasca Sarjana Institut Pertanian Bogor. Bogor.

Kamal, M. 1994.Nutrisi Ternak. Gadjah Mada University Press, Yogyakarta.

Kempen, T. A., T. G. Van and J. Odle. 1995. Carnitine effects octanoat oxidation to carbondioxide and dicarboxylic acids in colostrum-deprived piglets : In vivo analysis of mechanisms involved based on $\mathrm{CoA}$ and carnitine ester profiles. Journal of Nutrition 125: 238-250.

Kinsella, J. E. B. Lokesh and R. A. Stone. 1990. Dietary n-3 polyunsaturated fatty acids and amelioration of cardiovascular disease posible mechanism. The American Journal of Clinical Nutrition 52(1): 1-28.

Kleiner, I. S., and L. B. Dotti, 1962. Laboratory Instruction in Biochemistry sixth edition. The C. V. Mosby Company. New York.

Lin, D. S. and W. E. Connor. 1990. Are the n-3 fatty acids from dietary fish oil deposited in the triglyceride storoges of adipose tissue. The American Journal of Clinical Nutrition 51: 535539.

Lubis, D., E. Wina, B. Haryanto and T. Suhargiatmo. 2002. Effectiveness of Aspergillus Oryzae Fermentation Culture to Improve Digestion of Fibrous Feeds: In Vitro. Jurnal Ilmu Ternak dan Veteriner 7(2): 90-98.

Newton, I. S. 1996. Food enricment with long-chain n-3 PUFA. NFORM-CHAMPAIGN 7: 169-171.

Owen, K. Q., T. L. Weeden, J. L. Nelssen, S. A. Blum and R.D. Goodband. 1993. The effect of Lcarnitine addition on performance and carcass characteristic of growing-finishing swine. Journal of Animal Science 71(3): 656-662.

Owen, J. L. Nelssen, R.D. Goodband, T. L. Weeden and S.A. Blum. 1996. Effect of L-carnitine and soybean oil growth performance and body composition of early weaned pigs. Journal of Animal Science 74(7): 1612-1619.

Owen, L. H. Kim and C.S. Kim. 1997. The role of Lcarnitine in swine nutrition and metabolism. Korean Journal of Animal Nutrition and Food 21(1): 41-58.

Sardesai, V. M. 1992. Nutritional role of polyunsaturated fatty acids. Journal of Nutritional Biochemistry 3(4): 154-166.

Septiana, A. T, P. Yuwono, T. Setyowati dan T. Widyastuti, 1997. Pengaruh Pembakaran Daging Kambing, Ayam dan Itik pada Pembuatan Sate terhadap Pembentukan Produk Oksidasi Lemak. Laporan Hasil Penelitian. Fakultas Peternakan Universitas Jenderal Soedirman. Purwokerto.
Simopoulos, A. P. 1989. Summary of the NATO advanced research workshop on dietary $\omega-3$ and $\omega-6$ fatty acids: Bilogical effects and nutritional essentially. The Journal of nutrition 119(4): 521528.

Steel, R. G. D., and J.H. Torrie, 1980.Principles and Prosedures of Statistic. Mc Graw-Hill Inc. New York. Toronto. London.

Suarez, A. M. D. C. Ramires, M. J. Faus and A. Gil. 1996. Dietary long-chain polyunsaturated fatty acids influence tissue fatty acid composition in rats at weaning. Journal of Nutrition 126: 887897.

Sudibya, 1998. Manipulasi Kadar Kolesterol dan Asam Lemak Omega-3 Telur Ayam Melalui Penggunaan Kepala Udang dan Minyak Ikan Lemuru. Disertasi Program Pasca Sarjana IPB Bogor.

Sudibya dan S. Wasito, 2002. Penggunaan Kepala Udang Terhidrolisis dan Minyak Ikan Lemuru Terhadap Asam Lemak Omega-3, Omega-6 dan Kadar Kolesterol Daging Itik Tegal Periode Starter. Journal Animal Production. Fakultas Peternakan Unsoed, Purwokerto.

Sudibya, Suparwi, T. R. Sutardi, H. Soeprapto dan Y.Dwi, 2004. Produksi Daging Sapi Rendah Kolesterol Yang Kaya Asam Lemak Omega-3 dan Pupuk Organik dengan EM-4 Di Kelompok Martini Indah di Kabupaten Purwodadi. Proyek Pengembangan dan Peningkatan Kemampuan Teknologi Proyek Program Iptekda VI. LIPI. Jakarta. Lembaga Penelitian Univesitas Jenderal Soedirman Purwokerto.

Sudibya, D. Prabowo dan Hartoko, 2004. Suplementasi Enzim Selulase dan Ekstrak Asam Lemak Tak Jenuh Dalam Ransum Dasar Terhadap Kualitas dan Kuantitas Asam Lemak Tak Jenuh Telur Ayam. Journal Ilmiah. Lembaga Penelitian Unsoed. No.2 Vol. XXX. Edisi Juli Tahun 2004.

Sudibya, 2004. Peningkatan Kualitas Telur Ayam Melalui Suplementasi L-Karnitin dan Minyak Ikan Tuna Terhadap Kadar Asam Lemak Omega-3, Omega-6, Omega-9 dan Kadar Kolesterol. Fakultas Peternakan. Laporan Penelitian Lembaga Penelitian Unsoed. Purwokerto.

Sudibya, 2005. Suplementasi Prekursor Karnitin dan L-Karnitin serta Minyak Ikan Tuna Terhadap Kadar Kolesterol dan Asam Lemak Tak Jenuh Telur Itik Tegal. Fakultas Peternakan Unsoed Purwokerto.

Sudibya, S. Triatmojo dan H. Pratiknyo, 2006. Perbaikan Kualitas daging Sapi Melalui Transfer Omega-3 Terkapsul dan Tape Bekatul serta Produksi Pupuk Organik dengan Starter Gama95 di Kelompok Ternak Sapi Potong "Sidamaju" di Kabupaten Bantul. Proyek Pengembangan dan Peningkatan Kemampuan Teknologi Proyek 
Program Iptekda IX. LIPI. Jakarta. Lembaga Pengabdian Kepada Madyarakat Univesitas Jenderal Soedirman Purwokerto.

Sudibya, T. Widyastuti dan R. S. Santoso, 2008. Transfer Omega-3 Terkapsulisasi dan L-Karnitin Pengaruhnya Terhadap Komposisi Kimia Daging Kambing. Hibah Bersaing XIV. Laporan Penelitian Fakultas Peternakan Universitas Jederal Soedirman Purwokerto.

Sudibya, Darsono, dan P. Martatmo, 2009. Transfer Omega-3 Melalui Kapsulisasi dan L-Carnitin Pengaruhnya Terhadap Komposisi Kimiawi Air Susu Sapi Perah. Hasil Penelitian SINTA. Jurusan Peternakan Fakultas Pertanian Universitas Sebelas Maret Surakarta.

Sudibya, P. Martatmo, dan Sudiyono, 2009. Transfer Omega- 3 Terproteksi dan Minyak Kedele Dalam Ransum Bekatul Terfermentasi Terhadap Kadar Asam Linolenat, Linoleat dan Arakhidonat Air susu Sapi Perah.Laporan Penelitian Hibah SINTAProdi Peternakan Fakultas Pertanian Universitas Sebelas Maret. Surakarta

Sudibya, P. Martatmo, A. Ratriyanto dan Darsono, 2010. Transfer Omega- 3 Terproteksi dan LKarnitin Dalam Ransum Limbah Pasar Terfermentasi Terhadap Komposisi Kimiawi Daging Sapi Simental.Laporan Penelitian Hibah Kompetensi Prodi Peternakan Fakultas Pertanian Universitas Sebelas Maret. Surakarta.

Sudibya, P. Martatmo dan Darsono, 2012. Transfer Asam Lemak PUFA Terproteksi dan Precursor Karnitin Dalam Ransum Pengaruhnya Terhadap Komposisi Kimiawi Air Susu Kambing. Laporan Penelitian Hibah Bersaing. Prodi Peternakan Fakultas Pertanian Universitas Sebelas Maret.

Sudibya and S. H Purnomo. 2013. Transfer of Omega3 Fatty Acid Protected and Rice Bran Fermented in The Ration of Chemical Composition of milk Dairy Cow.Jurnal Media Peternakan. Animal Science and Technology 33(3): 222-229.

Sudibya, J. Riyanto dan A. I Sari, 2015. Transfer Lkarnitin dan asam lemak PUFA terproteksi dalam ransum limbah pasar terfermentasi pengaruhnya terhadap komposisi kimiawi air susu kambing. Journal of Rural and Development Puslitdesbangda. Vol VI

Sustriawan, B., R. Naufalin dan N. Aini, 2002. Mikroenkasulasi Konsentrat Asam lemak Omega-3 dari Minyak Ikan Tuna. Laporan Penelitian. Fakultas Pertanian Jurusan Teknologi Pertanian. Lembaga Penelitian Unsoed.

Tillman A. D., H. Hartadi, S. Reksohadiprodjo, S. Prawirokusumo, dan S. Lebdosoekojo. 1991. Ilmu Makanan Ternak Dasar. Gadjah Mada University Press. Yogyakarta.

Tranggono. 1986. Perubahan Lemak Selama Pemanasan dan Pengaruhnya terhadap Konsumen. Seminar Keamanan Pangan dan
Penyajian. Pusat Antar Universitas Pangan dan Gizi.UGM. Yogyakarta 1-3 September 1986.

Widiyastuti, T. C. H. Prayitno dan Sudibya. 2005. Pemanfaatan Kepala udang dan SuplementasiLKarnitin pada pakan Itik Lokal yang mengandung Daun Lamtoro Program Semi Que V Tahun II. Fakultas Peternakan Unsoed. Laporan Penelitian Program Studi Nutrisi Ternak.

Wyatt, C. L. and T. N. Goodman, 1993. Effect of LCarnitine and Dietary Lysine and FatLevels on Grwoh Performance and Body Lipid Content in Young Broilers. Poultry Science. 72: S149.

Yusmadi. 2008. Kajian mutu dan palatabilitas silase dan hay ransum komplit berbasis sampah organik primer pada kambing PE. Tesis. Bogor: Program Pascasarjana, Institut Pertanian Bogor. 